\title{
UTILIZATION OF CARP (Cyprinus carpio) AS SURIMI FOR SAUSAGE MANUFACTURING
}

\author{
Eveline $^{1^{*}}$, Joko Santoso ${ }^{1,2}$, Magnarai Huangdinata ${ }^{1}$ \\ ${ }^{1}$ Study Program of Food Technology, FaST, Pelita Harapan University \\ ${ }^{2}$ Study Program of Aquatic Product Technology, Faculty of Fisheries and Marine Science, IPB University. \\ UPH Tower, Lippo Karawaci, Tangerang 15811 / P.O.BOX 453 \\ Telp. (021)5460901 (Hunting), Fax: (021) 5460910 \\ *Korespondensi: eveline.fti@uph.edu \\ Diterima: 11 Juli 2019 /Disetujui: 25 Agustus 2019
}

Cara sitasi: Eveline, Santoso J, Huangdinata M. 2019. Utilization of carp (Cyprinus carpio) as surimi for sausage manufacturing. Jurnal Pengolahan Hasil Perikanan Indonesia. 22(2): 366-374.

\begin{abstract}
Carp (Cyprinus carpio) is a freshwater fish with high economic value and good farming potential. Carp-based product diversification could be done by using it as food ingredients such as surimi in sausage manufacture. This research was aimed to evaluate sausage produced from carp surimi by varying washing frequency and tapioca filler concentration. Five washing frequencies $(1 ; 2 ; 3$; and 4 times $)$ and three tapioca filler concentrations $(2 ; 3$; and $4 \%$ ) were compared. The study showed 1 time washing frequency gave better surimi physical characteristics $(57.40 \%$ yield; $73.76 \%$ water holding capacity; $26.64 \%$ expressible moisture content, 821.92 g.cm gel strength; $54.45 \%$ whiteness) and chemical characteristic (78.00\% moisture content and $6.34 \%$ salt soluble protein) compared to other washing frequencies. Based on the organoleptic test, $2 \%$ tapioca was the selected filler concentration. Selected surimi sausage had better physical, chemical and sensori characteristics than commercial sausage. The physical characteristics of the selected sausage were 70.46\% water holding capacity; $24.58 \%$ expressible moisture content; $78.64 \%$ whiteness; 4346.70 g.cm gel strength; $101.23 \mathrm{~g}$ hardness; $0.98 \mathrm{~g}$ springiness; and $43.96 \mathrm{~g}$ chewiness. While the chemical characteristics of that sausage were $75 \%$ water; $1.35 \%$ ash; $11.51 \%$ protein; $4.46 \%$ fat; and $7.63 \%$ carbohydrate. The sensory scores of the sausage evaluated were color 0.44 , aroma 0.60 ; taste 1.16 ; and springiness 1.86 .
\end{abstract}

Keywords: Cyprinus carprio, surimi, sausage

\section{Pemanfaatan Surimi dari Ikan Mas (Cyprinus carpio) untuk Pembuatan Sosis}

\begin{abstract}
Abstrak
Ikan mas (Cyprinus carpio) merupakan salah satu jenis ikan air tawar yang memiliki nilai ekonomis tinggi dan berpotensi baik untuk dibudidayakan. Diversifikasi produk berbahan dasar ikan mas dapat dilakukan dengan menjadikannya sebagai bahan baku produk pangan, contohnya surimi untuk pembuatan sosis. Penelitian ini bertujuan membuat sosis dari surimi ikan mas berdasarkan frekuensi pencucian ikan dan konsentrasi filler tepung tapioka. Penelitian diawali dengan menentukan frekuensi pencucian $(1 ; 2 ; 3$; dan 4 kali) berdasarkan karakteristik surimi terbaik. Pencucian sebanyak 1 kali menghasilkan karakteristik surimi terbaik dibandingkan frekuensi pencucian lainnya menurut karakteristik fisik (rendemen 57,40\%, daya ikat air 73,76\%, expressible moisture content $26,64 \%$, kekuatan gel 821,92 g.cm, derajat putih $54,45 \%$ ) dan karakteristik kimia (kadar air 78,00\% dan protein larut garam 6,34\%). Tahap selanjutnya dilakukan penentuan konsentrasi filler tepung tapioka (2; 3; dan 4\%) melalui uji organoleptik pada surimi pencucian terpilih. Tepung tapioka 2\% merupakan konsentrasi terpilih. Secara keseluruhan (aroma, rasa, rasa pahit, warna, dan kekenyalan), 70 panelis semi terlatih menerima produk ini (5,63 dari skala 7,00). Sosis surimi terpilih memiliki karakteristik fisik (daya ikat air 70,46\%, expressible moisture content 24,58\%, derajat putih 78,64\%, kekuatan gel 4346,70 g.cm, hardness 101,23 g, springiness 0,98 g, dan chewiness 43,96 g), karakteristik kimia (air 75\%, abu 1,35\%, protein 11,51\%, lemak 4,46\%, karbohidrat (by difference) 7,63\%), dan karakteristik sensori melalui uji perbandingan pasangan (warna 0,44, aroma 0,60, rasa 1,16, kekenyalan 1,86) lebih baik dibandingkan sosis komersial.
\end{abstract}

Kata kunci: Cyprinus carprio, ikan mas, gel, sosis, surimi 


\section{INTRODUCTION}

Carp (Cyprinus carpio) is one of freshwater fishes which are very popular in Indonesian. Carp processing on industrial scale has not existed until. Thus, one way to broaden carp utilization is to process it into surimi as a basic ingredient for making fish sausage. Amiza and Ain (2012) stated that surimi, also known as wet protein concentrate, can be defined as minced form of fish after deboning, washing, and dewatering. Surimi industry is profitable because it has the ability to be processed as advanced products (Rostini 2013). Surimi usually are made from gurami and stripped mullet Mugilecephalus, while carp utilization is still rare.

According to Fogaca (2013), washing frequencies is an important factor that could affect texture, color, and smell. Myofibril protein is able to bind water, lipid, and create gel (Nopianti et al. 2010). Washing treatment will eliminate lipid and sarcoplasmic protein so that myofibril protein concentration will rise (Chaijan et al. 2010). Characteristics of surimi are also affected by myofibril protein solubility, gel formation through crosslinking, fish freshness, heating temperature, and starch (Nopianti et al. 2010). According to Singal et al. (2013) and Agustin (2015), tapioca addition could increase emulsion viscosity and stability, as well as product characteristic because starch has the ability to bind water and increase formation of lipid emulsion. Agustina (2015) found that tapioca was a suitable filler for sausage due to its ability to produce clear solution, good gel strength, and shiny color in sausage products. This research was aimed to make fish sausage using surimi with various washing frequencies $(1 ; 2 ; 3$; and 4 times) and tapioca concentration $(2 ; 3$; and $4 \%)$ as filler.

\section{MATERIAL AND METHODS Research Procedures}

Carp was obtained from modern market Garding Serpong. Surimi was prepared according to Wijayanti et al. (2012) including deboning, gutting, mincing, washing and squeezing using filter cloth in order to gain filtrate. Washing was conducted with minced fish and water ratio of $1: 4$ at $\pm 5^{\circ} \mathrm{C}$
(Nopianti et al. 2012) with various frequencies ( $1 ; 2 ; 3$; and 4 times). In the last step, $0.3 \%$ $\mathrm{NaCl}$ was added. Surimi was then tested physically and chemically including protein (AOAC 2005) and salt soluble protein (Wijayanti et al. 2012) with Kjeldahl method, moisture and yied with oven method, lipid with Soxhlet method (AOAC 2005), expressible moisture content (Rawdkuen and Benjakul 2008), and water holding capacity (WHC) (Nopianti et al. 2012). Surimi was eventually processed into kamaboko according to modified method of Nugroho (2011), in which kamaboko making consist of: salt addition (2.5\%); boiling $\left(40^{\circ} \mathrm{C}, 20\right.$ minutes); further boiling $\left(90^{\circ} \mathrm{C}, 20\right.$ minutes); and cold water soaking $\left(5^{\circ} \mathrm{C}, 5\right.$ minutes). Kamaboko produced from each washing treatment was evaluated physically, i.e. gel strength (Amiza and Ain 2012) and whiteness (AOAC 2005) with TA-XT plus texture analyzer equipment.

Further analysis was carried out to determine tapioca concentration used in the manufacture of carp sausage. Concentration levels employed were 2 ; 3 ; and $4 \%$, in which those three levels were based on research conducted by Nico et al. (2014) and Widjanarko et al. (2012). The fish sausage processing was started by mixing thoroughly $250 \mathrm{~g}$ carp surimi with all remaining ingredients $2 \%(8 \mathrm{~g}), 3 \%(12 \mathrm{~g})$, or $4 \%$ (16 g) tapioca, $11 \mathrm{~g}$ sunflower seed, $3 \mathrm{~g}$ salt, $1 \mathrm{~g}$ garlic powder, $1 \mathrm{~g}$ pepper, $1 \mathrm{~g} \mathrm{STPP}$, and $125 \mathrm{~g}$ ice cube (Piotrowicz and Mellado 2015). The mixture was extruded into the casing and then boiled $\left(100^{\circ} \mathrm{C}, 15-20\right.$ minutes) to obtain carp sausage. The optimal tapioca concentration was determined using physical evaluation water holding capacity (Nopianti et al. 2012), expressible moisture content (Rawdkuen and Benjakul 2008), whiteness (AOAC 2005), gel strength (Amiza and Ain 2012), hardness, springiness, chewiness), chemical (proximate composition), and organoleptic evaluation (Lawless and Leymann 2010) and hedonic (Meilgaard et al. 2007) involving 70 semi trained panelist: color, aroma, taste, and springiness. Paired comparison test (Meilgaard et al. 2007) was carried out on the sausage with selected tapioca concentration 
and commercial fish sausage. Physical and proximate analysis was performed on the commercial sausage product.

\section{RESULTS AND DISCUSSION Proximate Composition of Carp}

Results of proximate composition analysis of was summarized in Table 1. Pratama et al. (2013) suggested that the production of surimi used fresh low-fat fish in order to prevent wet textured surimi which could not be processed further. The carp contained $79.55 \%$ of water and $16.47 \%$ of protein.

\section{Characteristic of Carp Surimi Yield}

Yield was used to reveal the economic value of surimi production. Higher yield means higher economic value to be utilized as raw material for further product processing (Rostini 2013; Shaviklo et al. 2012). Table 2 showed that greater washing frequency resulted in lower yield. due to loss of fish components (fish meat weight, sarcoplasmic protein, and fish lipid) (Rostini 2013).

\section{Water holding capacity (WHC)}

Water holding capacity is the ability of meat structure to hold water naturally (Walukonis et al. 2012). Water holding capacity plays important roles in gel and emulsion formation (Zhou et al. 2016). Table 2 demonstrated that greater washing frequency increased the WHC. According to Brown (2011), washing process affects amino acid composition, in which more washing frequencies increased the gap between myofibril filaments in surimi structure generating hydrophilic protein and trapping more water inside the surimi gel (Brown 2011; Ismail et al. 2010; and Sofiana 2012).

\section{Expressible moisture content}

Expressible moisture content reflects the ability of the surimi to release water from the sample. Table 2 showed that more washing frequencies improved surimi ability to release water. Washing increase surimi ability to hold water sreducing water release. Water retention in the surimi structure affect the formation of surimi gel. The results of the expressible moisture content analysis were not in accordance with the research conducted by Amiza and Ain (2012) because the weight used to hold surimi is ineffective so the results were biased.

\section{Gel strength}

Gel strength was measured by processing it into kamaboko which was stored for 24 hours in the refrigerator. Table 2 indicates that washing frequency increased the gel strength. Santoso et al. (2008) noted that gel strength increased when more washing was implemented. The washing process increases the distance between myofibril filaments

Table 2 Phase I research analysis results

\begin{tabular}{lccccc}
\hline \multirow{2}{*}{ Parameter } & \multicolumn{5}{c}{ Result } \\
\cline { 2 - 6 } & Unit & Washing 1 & Washing 2 & Washing 3 & Washing 4 \\
\hline Physical characteristics & $\%$ & $57.40 \pm 2.90$ & $48.76 \pm 3.00$ & $37.47 \pm 0.87$ & $36.00 \pm 2.04$ \\
\hline Yield & $\%$ & $73.76 \pm 1.61$ & $74.52 \pm 2.20$ & $75.12 \pm 5.83$ & $76.19 \pm 4.70$ \\
WHC & $\%$ & $26.64 \pm 1.39$ & $28.07 \pm 1.27$ & $30.03 \pm 1.70$ & $31.88 \pm 1.36$ \\
Expressible moisture content & g.cm & $821.92 \pm 20.49$ & $846.06 \pm 5.39$ & $851.05 \pm 2.36$ & $862.75 \pm 4.77$ \\
Gel strength & $\%$ & $52.45 \pm 0.32$ & $52.49 \pm 0.17$ & $59.87 \pm 3.49$ & $55.14 \pm 0.76$ \\
Whiteness & $\%$ & & & & \\
\hline Chemical characteristics & $\%$ & $78.00 \pm 1,14$ & $83.12 \pm 0.65$ & $84.16 \pm 0.47$ & $89.93 \pm 0.13$ \\
\hline Moisture content & $\%$ & $6.34 \pm 0,12$ & $5.11 \pm 0.50$ & $4.66 \pm 0.16$ & $4.07 \pm 0.04$ \\
Salt soluble protein & &
\end{tabular}

Notes: Treatment was not compared between analysis 
which results in a hydrophilic protein and a stronger water trap in the gel.

\section{Whiteness Degree}

Whiteness degree indicates the surimi quality from color aspect with the value in the range of $0-100$. White colour shows good surimi quality. Table 2 reveals that the three time washing produced surimi with better whiteness degree compared to others. According to Ramadhan et al. (2014), washing treatment is able to improve surimi whiteness degree. Washing treatment will release away component in the fish so that the whiteness degree of the surimi improves. Bledso et al. (2010) noted that fish which needs high amount of sodium bicarbonate $\left(\mathrm{NaHCO}_{3}\right)$ addition requires washing treatment in order to increase the whiteness degree of surimi.

\section{Moisture content}

Moisture content analysis was carried out to determine the amount of water trapped in surimi gel. Table 2 demonstrates that washing process increased moisture content of surimi. Ismail et al. (2010) informed that $\mathrm{Cl}^{-}$in salt used as solvent for myofibril protein will bind to a positive bond increasing the distance between filaments. An increase in the gap will trap and capture water in the surimi network.

\section{Salt soluble protein}

Salt soluble protein analysis was directed to determine the myofibril protein contained in surimi. According to Wijayanti et al. (2012), myofibril protein makes up 55-60\% of total protein, in which other proteins are sarcoplasmic and connective tissue proteins. Salt addition up to $3 \%$ was needed in this analysis in order to produce elastic effect from the myofibril protein. Table 2 shows that the increasing frequency of washing reduced the salt soluble protein concentration. According to Wijayanti et al. (2012), increasing washing frequency washed myofibril protein away, reducing the salt soluble protein concentration.

\section{Best surimi selection}

According to Rostini (2013), Wijayanti et al. (2012), and Amiza and Ain
(2012), good surimi is characterized by high yield and salt soluble protein, and low expressible moisture content. High yields indicates that more material or ingredients can be further utilized or processed. The presence of salt soluble protein in surimi indicates that high myofibril protein is available to be involved in gel formation of a product. Expressible moisture content value is expected low so that the surimi can hold more water during gel formation. Based on the results of quality analysis and the criteria of good surimi, the product with one washing was considered the best and selected as surimi for further research phase, i.e. carp sausage making. Properties of surimi with one washing frequency were $57.40 \pm 2.90 \%$ yield, $73.76 \pm 1.61 \%$ WHC, $26.64 \pm 1.39 \%$ expressible moisture content, $821.92 \pm 20.49$ g.cm gel strength, $52.45 \pm 0.32 \%$ whiteness, $78.00 \pm 1.14$ whiteness, $6.34 \pm 0.12 \%$ salt soluble protein.

\section{Carp Sausages Organoleptic Characteristic}

Carp sausage prepared using surimi with one time washing and various tapioca levels was evaluated organoleptically in terms of aroma, taste, bitterness, color, springiness, and overall acceptability (Table 3 ). The addition of $2 \%$ tapioca tend to produce better fish sausage and is preferred by panelists. Increasing tapioca concentration reduces the aroma acceptability by panelists $(\mathrm{p}<0.05)$. According to Wulandari et al. (2013), lower level of tapioca addition induced stroner fish smell. Just like the aroma, panelist tend to like the taste of surimi with $2 \%$ tapioca. The addition of tapioca also reduces the panelist acceptability for taste parameter $(\mathrm{p}<0.05)$. The addition of 3 and $4 \%$ starch in carp sausage produced starchy taste product, while $2 \%$ addition level of starch resulted in more acceptable sausage organoleptically for panelist (Lestari et al. 2011; Singal et al. 2013). Tapioca is made of cassava having naturally bitter taste. Sausage prepared with $2 \%$ tapioca addition was more acceptable organoleptically because the cassava bitterness was probably masked by the fish (Wulandari et al. 2013). Tapioca addition will result in the increment of tapioca amount in the sausage, bringing about the product 
Table 3 Organoleptic score of carp sausage

\begin{tabular}{lccc}
\hline \multirow{2}{*}{ Hedonic } & \multicolumn{3}{c}{ Tapioca concentration } \\
\cline { 2 - 4 } & $2 \%$ & $3 \%$ & $4 \%$ \\
\hline Aroma & $5.41 \pm 1.08^{\mathrm{c}}$ & $4.87 \pm 1.27^{\mathrm{b}}$ & $4.36 \pm 1.48^{\mathrm{a}}$ \\
Taste & $5.56 \pm 1.04^{\mathrm{b}}$ & $4.77 \pm 1.32^{\mathrm{a}}$ & $4.59 \pm 1.55^{\mathrm{a}}$ \\
Bitterness & $5.43 \pm 1.25^{\mathrm{b}}$ & $5.00 \pm 1.46^{\mathrm{ab}}$ & $4.67 \pm 1.50^{\mathrm{a}}$ \\
Color & $5.23 \pm 1.24^{\mathrm{a}}$ & $4.96 \pm 1.06^{\mathrm{a}}$ & $4.77 \pm 1.26^{\mathrm{a}}$ \\
Springiness & $5.61 \pm 0.95^{\mathrm{b}}$ & $4.81 \pm 1.20^{\mathrm{a}}$ & $4.66 \pm 1.44^{\mathrm{a}}$ \\
Overall & $5.63 \pm 0.82^{\mathrm{c}}$ & $5.04 \pm 1.06^{\mathrm{b}}$ & $4.66 \pm 1.40^{\mathrm{a}}$ \\
\hline
\end{tabular}

Notes: Treatment was not compared between analysis

acceptability by panellists to decrease $(\mathrm{p}<0,05)$.

Tapioca addition did not affect color of carp sausage ( $\mathrm{p}>0.05)$. Agustina (2015) and Alamsyah (2005) noted that tapioca addition for $2 ; 3$; and $4 \%$ did not contribute significantly to the color of end product. The tapioca addition level reduced sausage springiness $(\mathrm{p}<0.05)$. Prastini and Simon $(2015)$ revealed that tapioca addition in sausage produced softer product texture. In general, panelists preferred the fish sausage added with $2 \%$ tapioca with overall acceptabiity score of 5.63 (slightly like).

Based on the above results of organoleptic evaluation, the addition of $2 \%$ tapioca in carp sausage processing produced the best product and that tapioca addition level is recommended to be employed. In order to explore product feasility, the phycochemical characteristics of carp sausage added $2 \%$ tapioca was compared with the commercial products.

\section{Physicochemical characteristics of carp sausage and commercial sausage}

Sausage characteristics were explored through physical (WHC, expressible moisture content, whiteness, gel strength, hardness, springiness, and chewiness) and chemical (water, ash, protein, and carbohydrate) analyses. All characteristics of carp sausage were compared to that of of commercial product (Table 4). The ability of sausage emulsions to hold water naturally (WHC) was higher than that of commercial sausage $(\mathrm{p}<0.05)$. Washing treatment applied to intermediate product makes the gap between filaments of myofibril open s trapping water in the surimi gel (Purnomo et al. 2011; Brown 2011; Ismail et al. 2010; Nopianti et al. 2012 and Sofiana 2012).

Expressible moisture content of carp sausage was higher compared to that of commercial sausage $(p<0.05)$. According to Amiza and Ain (2012), expressible moisture content can be reduced through washing. Washing can make surimi sausage matrix thighter and keep the water from releasing. Results were not in accordance to the previous research because of the weight used to hold the surimi was not effective.

Whiteness degree of carp sausage was higher than that of commercial sausage. The introduction of washing can remove some fish component (blood and dirts), so the product looks cleaner (Ramadhan et al. 2014). Previous study conducted by Poernomo et al. (2011) and Singal et al. (2013) also produced fish sausage with higher whiteness degree compared to commercial sausage.

Gel strength of carp sausage was higher than that of commercial sausage $(\mathrm{p}<0.05)$. Gel strength increased due to washing treatment, because the gap between myofibril filaments will open so that it is hydrophilic and stronger to hold water in the gel (Santoso et al. 2008).

Hardness of carp sausage was lower than that of commercial sausage $(\mathrm{p}<0.05)$. Washing process in surimi prior to sausage production probably reduced hardness through increasing WHC and gel strength of sausage. Carp sausage obtained would keep more water in gel matrix yielding softer final texture than the commercial sausage. 
Table 4 Characteristic comparison between selected carp sausage and commercial sausage

\begin{tabular}{lccc}
\hline Parameters & Carp Sausage & $\begin{array}{c}\text { Commercial } \\
\text { Sausage }\end{array}$ & $\begin{array}{c}\text { Catfish Surimi } \\
\text { Sausage }\end{array}$ \\
\hline Physical characteristics & & & \\
\hline Water holding capacity (\%) & $70.46 \pm 0.23^{\mathrm{b}}$ & $54.61 \pm 0.24^{\mathrm{a}}$ & 79.36 \\
Expressible moisture content (\%) & $24.58 \pm 1.58^{\mathrm{b}}$ & $13.02 \pm 0.25^{\mathrm{a}}$ & - \\
Whiteness (\%) & $78.64 \pm 0.85^{\mathrm{b}}$ & $64.64 \pm 0.48^{\mathrm{a}}$ & 72.67 \\
Gel strength (g.cm) & $4346.70 \pm 256.71^{\mathrm{b}}$ & $3269.91 \pm 123.80^{\mathrm{a}}$ & 4220.55 \\
Hardness (g) & $101.23 \pm 9.50^{\mathrm{a}}$ & $103.49 \pm 1.95^{\mathrm{b}}$ & - \\
Springiness (g) & $0.98 \pm 0.01^{\mathrm{b}}$ & $0.78 \pm 0.01^{\mathrm{a}}$ & - \\
Chewiness (g) & $43.96 \pm 2.03^{\mathrm{a}}$ & $65.09 \pm 4.20^{\mathrm{b}}$ & - \\
\hline Chemical characteristics & & & 70.14 \\
\hline Moisturer content & $75.05 \pm 1.18^{\mathrm{b}}$ & $55.00 \pm 0.20^{\mathrm{a}}$ & - \\
Ash content & $1.35 \pm 0.02^{\mathrm{a}}$ & $1.56 \pm 0.07^{\mathrm{a}}$ & 10.27 \\
Protein content & $11.51 \pm 0.59^{\mathrm{b}}$ & $6.49 \pm 0.08^{\mathrm{a}}$ & - \\
Lipid content & $4.46 \pm 0.24^{\mathrm{a}}$ & $13.65 \pm 0.08^{\mathrm{b}}$ & - \\
Carbohydrate content & $7.63 \pm 0.33^{\mathrm{a}}$ & $23.30 \pm 0.43^{\mathrm{b}}$ & - \\
\hline
\end{tabular}

Notes: ${ }^{*}$ Physical characteristic analysis by Poernomo et al. (2011)

The springiness score of carp sausage was higher than that of commercial sausage $(\mathrm{p}<0.05)$. Agustina (2015) and Santoso et al. (2008) revealed that surimi sausage made from washed intermediate ingredients would be able to hold water better resulting in higher springiness score.

Carp sausage showed lower chewiness score compared to commercial sausage $(p<0.05)$. Chewiness is the ability of food products to return to their original form after being pressed. Carp sausage matrix could not produce the same chewiness as commercial sausages, although the carp sausage gel structure had better WHC, gel strength, and springiness compared to commercial sausage. According to Agustina (2015), chewiness score should correspond to hardness because the gel structure formed by polypeptide protein and amylopectin polysaccharide were able to resist the probe's pressure making the elasticity lower than the commercial sausage. In the end, surimi sausage produced was harder (not elastic enough) compared to commercial sausage.

Carp sausage had higher moisture and protein content compared to commercial sausage $(\mathrm{p}<0.05)$. Washing process made more water trapped in the gel matrix (Pratama et al. 2013). Poernomo et al. (2011) also noted higher moisture content in catfish sausage than commercial sausage. The moisture content of carp sausage in this study exceeded maximum level according to Indonesia National Standard (SNI) for sausage, i.e. $67.7 \%$ (BSN 1995). Likewise, protein content of carp sausage was also higher compared to commercial sausage $(\mathrm{p}<0.05)$, but the value was lower than the minimum protein level for sausage of SNI, i.e.13\%. Poemomo et al. (2011) also revealed the same result. According to Widjanarko et al. (2012), commercial sausages wereprocessed using ingredients other than fish as filler and fish substitutes resulting in sausage with lower protein content.

\section{Organoleptic characteristic of carp sausage and commercial sausage}

Organoleptical evaluation using paired comparison test was conducted with hedonic parameter of color, aroma, taste, and springiness. Semi trained panelists evaluated carp sausage based on reference (R), i.e. commercial sausage. The evaluation revealed that the score for each organoleptic parameter 
was color 0.44 , aroma 0.60 , taste 1.16 , and springiness 1.86 . The above results indicated that carp sausage was organoleptically better thsn commercial sausage.

\section{CONCLUSIONS}

The washing process affected the characteristics of carp surimi as the basic ingredients of carp surimi sausages The use of binder concentration played an important role to produce physical characteristics (water holding capacity, expressible moisture content, gel strength, hardness, springiness, and chewiness) chemical (moisture, ash, protein, lipid, carbohydrate), and organoleptic (aroma, taste, bitter taste, color, chewiness, and organelptik as a whole acceptance) carp surimi sausage.

\section{REFERENCES}

Afkhami M, Mokhlesi A, Bastami KD, Khoshnood R, Eshaghi N, Ehsanpour M. 2011. Survey of some chemical compositions and fatty acids in cultured common carp (Cyprinus carpio) and grass carp (Ctenopharyngodon idella). World Journal of Fish and Marine Sciences. 3: 533-538.

Agustina AIT. 2015. Pengaruh penambahan angkak dan jumlah tapioka terhadap sifat organoleptik sosis udang. Jurnal Tata Boga. 4(3): 30-38.

Alamsyah Y. 2005. Membuat Sendiri Frozen Food: Sosis Tanpa Bahan Pengawet. Jakarta (ID): PT Gramedia Pustaka.

Amiza MA, Ain KN. 2012. Effect of washing cycle and salt addition on the properties of gel catfish (Pangasius sp.) surimi. International Annual Symposium of Sustainability Science and Management 11: 485-491.

[AOAC] 2005. Official Methods of Analysis of the Association of Official Analytical Chemists $18^{\text {th }}$ ed. Virginia (US): AOAC, Inc.

[BSN] Badan Standardisasi Nasional. 1995. Sosis Daging-SNI 01-3820-1995. Jakarta (ID): Badan Standardisasi Nasional.

Bledso GE, Rasco BA, Piggot GM. 2010. The effect of biocarbonate salt addition on The gel forming properties of Allaska pollock (Theragra chalcogma) and Pasific whiting (Merchuccus products) surimi. Journal of Aquatic Food Product Technology. 9(1): 31-45.

Brown A. 2011. Understanding Food. New York (US): Wadsworth Cengage Learning. Chaijan M, Panpipat W, Benjakul S. 2010. Physicochemical properties and gel forming ability of surimi from three species of mackerel caught in Southern Thailand. Food Chemistry. 121: 85-92.

Fogaca FHS, Luzia AT, Aurea JB, Lea SS. 2013. Optimization of the surimi production from mechanically recovered fish meat (MRFM) using response surface methodology. Journal of Food Quality. 36: 209-216.

Hadjinikolova L. 2008. Investigations on the chemical composition of carp (Cyprinus carpio L.), bighead carp (Aristichthys nobilis Rich.) and pike (Esox lusius L.) during different stages of individual growth. Bulgarian Journal of Aglicultural Science. 14: 121-126.

Ismail I, Huda $\mathrm{N}$, Ariffin $\mathrm{F}$, Ismail $\mathrm{N}$. 2010. Effect of washing on the functional properties of duck meat. International Journal of Poultry Science. 9(6): 556-561.

Lawless HT, Leymann H. 2010. Sensory Evaluation of Food: Principles and Practices $2^{\text {nd }}$ ed. New York (US): Springer.

Lestari S. 2011. Penggunaan bahan pencuci alkali dan perendaman fillet dalam pembuatan surimi pada formulasi pempek patin (Pangasius pangasius). [Thesis]. Bogor (ID): Teknologi Hasil Perairan Institut Pertanian Bogor.

Meilgaard MC, Civille GV, Carr BT. 2007. Sensory Evaluation Techniques $4^{\text {th }}$ ed. Boca Raton (US): CRC Press.

Nico M, Putut HR, Ima W. 2014. Pengaruh penambahan karagenan terhadap kualitas sosis ikan kurisi (Nemipterus sp.) dan sosis ikan nila (Oreochromis sp.). Jurnal Pengolahan dan Bioteknologi Hasil Perikanan. 3(2): 99-105.

Nopianti R, Huda N, Noryati I. 2010. Loss of functional properties of proteins 
during frozen storage and improvement of gel-forming properties of surimi. Asian Journal of Food and Agro-Industry. 3(6): 535-547.

Nopianti R, Huda N, Fazilah A, Ismail N, Easa AM. 2012. Effect of Different Types of Low Sweetness Sugar on Physic Chemical Properties of Threadfin Bream Surimi (Nemipterus spp.) during Frozen Storage. International Food Research Journal 19:1011-1021.

Nugroho F. 2011. Pengaruh pengkomposisian dan penyimpanan dingin terhadap karakteristik surimi ikan air tawar. [Thesis]. Tangerang (ID): Universitas Pelita Harapan.

Piotrowicz IBB, Mellado MMS. 2015. Chemical, technological, and nutritional quality of sausage processed with surimi. International Food Research Journal. 22(5): 2103-2110.

Poernomo D, Pipih S, Nisa N. 2011. Karakteristik sosis rasa ayam dari surimi ikan lele dumbo (Clarias gariepinus) dengan penambahan isolat protein kedelai. Jurnal Pengolahan Hasil Perikanan Indonesia. 14(2): 106-114.

Prastini AI, Simon BW. 2015. Pembuatan sosis ayam menggunakan gel porang (Amorphophallus mueleri Blume) sebagai bahan pengikat terhadap karakteristik sosis. Jurnal Pangan dan Agroindustri. 3(4): 1503-1511.

Pratama RI, Iis R, Muhammad YA. 2013. Komposisi kandungan senyawa flavor ikan mas (Cyprinus carpio) segar dan hasil pengukusannya. Jurnal Akuatika. 4(1): 0853-2523.

Ramadhan K, Huda N, Ruzita R. 2014. Effect of number and washing solutions on functional properties of surimi-like material from duck meat. Journal Food Science Technology. 51(2): 256-266.

Rawdkuen S, Benjakul S. 2008. Whey protein concentrate: autolysis inhibition and effects on the gel properties of surimi prepared from tropical fish. Food Chemistry. 106: 1077-1084.

Rostini I. 2013. Pemanfaatan daging limbah fillet ikan kakap merah sebagai bahan baku surimi untuk produk perikanan. Jurnal Akuatika. 4(2): 141-148.

Santoso J, Ade WN, Yasin, Santoso. 2008. Perubahan karakteristik surimi ikan cucut dan ikan pari akibat pengaruh pengkomposisian dan penyimpanan dingin daging lumat. Jurnal Teknologi dan Industri Pangan. 19(1): 57-65.

Shaviklo GR, Thorkelsson G, Arason S, Sveinsdottir K. 2012. Characteristics of freeze-dried fish protein isolated from saithe (Pollachius virens). Journal Food Science Technology. 49: 309-318.

Singal CY, Erny JNN, Teltje K, Gregoria SSD. 2013. Pengaruh penambahan tepung wortel (Daucus carota L.) pada pembuatan sosis ikan gabus (Ophiocephalus striatus). Jurnal Ilmiah. 3(6): 1-8.

Sofiana A. 2012. Penambahan tepung protein kedelai sebagai pengikat pada sosis sapi. Jurnal Ilmiah Ilmu-Ilmu Peternakan. 15(1): 1-7.

Uju RN, Ibrahim B. 2016. Pengaruh frekuensi pencucian surimi terhadap mutu produk bakso ikan jangilus (Istiophorus sp.). [Thesis]. Bogor (ID): Institut Pertanian Bogor.

[USDA]. The United States Department of Agriculture. 2012. Fish, carp, raw. https:// ndb.nal.usda.gov/.

Walukonis CJ, Morgan MT, Gerrard DE, Forrest JC. 2012. A technique for predicting water-holding capacity in early postmortem muscle. West Lafayette (IN): Swine Research Report.

Widjanarko SB, Khalil, Elok Z, Aan MK. 2012. Studi kualitas fisik-kimiawi dan organoleptiksosisikanleledumbo(Clarias gariepinus) akibat pengaruh perebusan, pengukusan, dan kombinasinya dengan pengasapan. Jurnal Teknologi Pertanian. 4(3): 193-202.

Wijayanti I, Santoso J, Agus MJ. 2012. Pengaruh frekuensi pencucian terhadap karakteristik gel surimi ikan lele dumbo (Clarias gariepinus). Jurnal Saintek Perikanan. 8(1): 32-37.

Wulandari D, Nur K, Sumardi HS. 2013. Perekayasaan pangan berbasis produk lokal Indonesia (studi kasus sosis 
berbahan baku tempe kedelai). Jurnal Bioproses Komoditas Tropis. 1(2): 73-82.

Zhou A, Benjakul S, Pan K, Gong J, Liu X. 2016. Cryoprotective effect of threhalosa and sodium lactate on tilapia (Sarotherodon nilotica) surimi during frozen storage. Food Chemistry. 96: 96-103. 